BORIS SAPIR

\title{
JEWISH SOCIALISTS AROUND VPERED ${ }^{1}$
}

SOCIALIST PROPAGANDA AMONG JEWS AND VPERED

The importance of the "Lavrists" or "Vperedovtsy", named after the publication Vpered (Forward) (1873-1877) founded and edited by Peter Lavrovich Lavrov, in the evolution of the socialist ideas and groups in Russia has been recognized by historians from Alphonse Thun to Franco Venturi. ${ }^{2}$ The journal's role in the dissemination of the socialist credo among Russian Jews has never been seriously disputed, although seldom recorded in concrete terms.

Of the leading Lavrists only Nicolas Kuliabko-Koretskii left memoirs. ${ }^{3}$ But he, as well as Lavrov who compiled an interesting outline of the main phases of the "Narodnichestvo"4 were not exceedingly interested in the Jewish aspect of their oeuvre. They touched this topic only in passing and, if at all, referred to Liberman whose Jewish socialism captivated their imagination. There was no reason for them to indicate and to dwell on the Jewish origin of socialist Jews in their midst who never associated themselves with any Jewish cause or aspirations. The outsiders who did so many years afterwards, knew too little about the internal affairs of $V$ pered and, therefore, either exaggerated its influence among Jews or underestimated the importance of leading Jewish Lavrists or, which

1 With slight changes this paper was read at the YIVO Research Conference on Jewish participation in movements devoted to the cause of social progress, New York, September IO-I $3, \mathrm{I}^{2} 64$.

2 A. Thun, Geschichte der revolutionären Bewegung in Russland, Leipzig 1883 ; F. Venturi, Roots of Revolution, London I960. The reader of this journal may find a condensed treatment of the position and influence of Vpered in Boris Sapir, Unknown Chapters in the history of Vpered, in: International Review of Social History, Vol. II (1957), pp. 52-54.

${ }^{3}$ N. G. Kuliabko-Koretskii, Iz davnikh let, Vospominaniia lavtista, Moscow I93I.

- Narodniki-Propagandisty $1873-1877$ godov, in: Materialy dlia istorii russkogo revoliutsionnogo dvizheniia, Vol. X, Genève I 895 . 
happened more often, left out names of several Jews who belong to the story.

A sweeping statement by Leo Deutsch that "Jews in their majority [i.e., Jewish revolutionaries in the 'seventies] joined the Lavrists"1 was already contended before it was published. Pavel Axelrod, whom Deutsch asked for advice, warned his old friend: "I do not know where you found that Jews were drawn toward 'Lavrism'... it seems to me that it is a product of a phantasy or a tempting hypothesis". ${ }^{2}$

The connection of Vpered with Aron Liberman and his group of Jewish socialists, considered as initiators of the Jewish socialist and labor movement, ${ }^{3}$ is well known. Here it is not the place even to summarize the manifold studies on Liberman. We want solely to recapitulate the most striking points in the relationship between $V$ pered and the pioneers of Jewish socialism.

Liberman escaped from Vilno in the summer of 1875 and was introduced to the editorial circle of Vpered, then in London, by the leader of the Lavrists in Russia, Lev Ginsburg, about whom we will have to tell much more a little later. In his introductory letter Ginsburg mentioned that he used to stay at Liberman's home in Vilno during his visits there on party affairs. ${ }^{4}$ In London Liberman learned a compositor's trade and became typesetter in the printing shop of $V$ pered. He also illustrated some pamphlets put out by $V$ pered. Last but not least, he wrote a series of articles for the Vpered bi-monthly. ${ }^{5}$ During his stay in London, Liberman launched an appeal to the Jewish young intelligentsia ${ }^{6}$ and drafted a charter of a Jewish socialist

1 L. Deutsch (Deich), Rol' evreev v russkom revoliutsionnom dvizhenii, Vol. I, Berlin I923, p. 54 .

2 Undated lettex, preserved in the Axelrod archives in the Internationaal Instituut voor Sociale Geschiedenis, Amsterdam.

3 See S. Tsinberg, Pervye sotsialisticheskie organy na evreiskom iazyke, in: Perezhitoe, Vol. I, St. Petersburg I908, p. 235; E. Tscherikower, Der onheyb fun der yiddisher sotsialistisher bavegung, in: Historishe Shriftn, Vol. I, Warsaw r 929, pp. 49 I, 492 and 9 I I. For a detailed treatment of Liberman's role in the socialist movement see: B. Sapir, Liberman et la socialisme russe, in: International Review for Social History, Vol. III (1938), pp. 25-88. This study and the present one are largely based on the archives of Valerian Nikolaevich Smirnov, the secretary of Vpered. These archives are preserved in the IISG and I was privileged to make copious notes from them prior to World War II.

- Ginsburg to the redaction of Vpered early in August, 1875 . This and some other letters of or concerning Liberman have been published in the International Review for Social History, Vol. III (1938), pp. 59-88.

s "From Vilno", I 875, nrs. I6 and 21 ; 1876, nrs. 32, 35 and 37; "From Bialystok", I 875 , nrs. 18, 19, 20, 23 and $24 ; 1876$, nrs. 26 and 27 and "Indirect Result of the Governmental Panic", ז 875 , nr. 18.

- Evreiskoi intelligentnoi molodezhi, in: Vpered, the bi-monthly edition, 1876, nr. 38. 
section of the so called "Russian Social-Revolutionary Party", ${ }^{1}$ both of which were conceived and executed in the spirit of the Russian socialist ideas of that time.

In his appeal Liberman refers to the debt of the Jewish intelligentsia towards the Jewish proletariat and urges Jewish youth "to go to the people". A propos, Liberman envisaged the building up of socialist cadres in the same manner as Vpered and its editor Peter Lavrov, i.e., the intelligentsia should disseminate socialist notions among the working classes, bring up conscious men and women and then cede the leadership to this intelligentsia that was really of the people. Exactly this role Liberman recommends to the Jewish academic and high school students. ${ }^{2}$ From Smirnov's letters to his first wife, Rozalia Idelson, to whom we consign a special section, we do know that Liberman discussed thoroughly with Lavrov and Smirnov the appeal to the Jewish young intelligentsia and that there existed a draft of this appeal which Liberman destroyed under the impact of critical comments made by Lavrov and Smirnov when he asked their advice.

Even much closer was the cooperation between Liberman and Vpered, represented this time by Peter Lavrov, in the preparation of the charter of a Jewish section of the "Russian Social-Revolutionary Party". Letters by Smirnov and by Lavrov to Rozalia Idelson present evidence of the active participation of Lavrov in writing up the charter. Besides, the wording of this charter reflects to such an extent the personal views of Lavrov, is full of favorite expressions and thoughts of the latter, that the charter should be considered, at least, a common document of both, Lavrov and Liberman. The perusal of the booklet "To the Russian Social-Revolutionary Youth"3 written by Lavrov against Tkachev in 1874 and of his book "Government in the Society of the Future"4 published in 1876 would prove this point.

$V$ pered also had its share in the establishment of the first Jewish socialist organization "Agudah Hasotsialistim Haivrim", set up in London in May 1876 . To begin with, the most articulate of the ten founding members of the Agudah were Liberman, Goldenberg, Saper and Weiner. The first two formed part of the Vpered technical staff, and Saper and Weiner belonged to the readers and admirers of the publication who, as long as they remained interested in public affairs,

1 Ustav sotsial'no-revoliutsionnogo soiuza sredi evreev v Rossii, see N.A. Bukhbinder, Iz istorii revoliutsionnoi propagandy sredi evreev v Rossii $\mathrm{v} 70-\mathrm{kh} \mathrm{gg}$, in: IstorikoRevoliutsionnyi Sbornik, Vol. I, Moscow-Petrograd 1924, pp. 37-66.

2 Vpered, the bi-monthly edition, I 876, nr. 27, pp. 83-84.

S Russkoi sotsial'no-tevoliutsionnoi molodezhi, London 1874 .

- Gosudarstvennyi element v budushchem obshchestve, London 1876. 
got their political mots d'ordre from Vpered and who, after the discontinuance of $V$ pered, maintained close contact with Lavrov and Smirnov. Furthermore, the plan to establish the Agudah emerged in the midst of the Vpered community in London and it is not clear at all whether or not it was Liberman who conceived this plan. In his letters to Rozalia Idelson, Smirnov claims that it was he who suggested to found a Jewish Socialist group as a vehicle for the organization of trade-unions in Whitechapel. Be that as it may, the Agudah was not the favored child of Liberman who had remained faithful to his vision - publication of a Jewish Socialist newspaper and who found ways and means to put out Haemes (The Truth) in I $877 .{ }^{1}$ The statutes of the Agudah written by Liberman were published in Vpered ${ }^{2}$ and it was typical for a pupil of Lavrov to insert there that the relationship of the Agudah members in and outside the organization should be based on truth, justice and morality.

Vpered emphatically welcomed the birth of Agudah and on this occasion extended a greeting to Jewish workers, referring to them as "brothers in a common cause and in humanity" 3 who have to overcome many more difficulties than their Russian fellow fighters. The author of these encouraging words was nobody else than Valerian Smirnov. ${ }^{4}$

Vpered stood out for its attitude in the Jewish question. Not that the cosmopolitan outlook of Lavrov and Smirnov formed an exception. On the contrary, it was rather the rule. But both of them were consistent and never adhered to the facile generalizations current in certain socialist circles of the 'seventies and even condoned by some Jewish revolutionaries, who themselves did not refrain from referring to Jews as kikes ( $z$ bidy) and considered the Jews as a parasitic nation which exploits poor peasants and worships a golden calf.

Lavrov and Smirnov steered their Vpered clear of any anti-semitic allusions, not to speak of direct anti-Jewish attacks. Thus, they refused to print an Ukrainian translation of a Russian socialist pam-

1 Vienna, May-September - 3 issues.

- See: Osnovanie sotsial'no-revoliutsionnogo obshchestva evreiskikh rabotnikov $\mathbf{v}$

Londone, in: Vpered, the bi-monthly edition, 1876 , nr. 37, pp. 454-55.

3 Idem, p. 455.

- For the history of the Agudah cf. E. Tscherikower, op. cit. 
phlet $^{1}$ provided by the translator, at his own initiative, with antisemitic slogans. They actually re-wrote a story received from Moscow under the heading "A Storm is Near" in order not to print characteristics of Jews, used by the author of this story, which could be misinterpreted by Jew baiters. ${ }^{2}$ They were perfectly aware of the smoldering distrust against Jews, primarily among certain Ukrainian socialists. Thus, Sergei Podolinskii, a well known socialist leader in the Ukraine, an old acquaintance of Ginsburg, Sminov and Rozalia Idelson, a man who played not the least important role in the organization of Vpered, wrote on June 19, 1876 to Smirnov: "Except for few cases which do not warrant special attention, I deny the existence and even the possibility of the existence in Russia (not only in the Ukraine) of socialist zhidy completely sincere in their behaviour as a socialist should be." May be for this reason Vpered preferred to drop from a correspondence published in 1876 of its bi-monthly edition under the signature "Moskvich" a paragraph which read: "You, Jewish young people, cast off any softness and compliance. One of your co-religionists showed weakness in the IIIrd Department [political police] where he had been for two months only and now he tears his hair."3

May be for similar reasons or following the old adage "quieta non movere", Vpered refrained from inserting an impassionate indictment of anti-semitic feelings among Russian socialists under the heading "Prejudices of our Social Revolutionaries against Jews." This indictment in the form of a lengthy article, reached Vpered from Russia via Berlin in 1876 . In Berlin, at that time, there existed a group of academic students from Russia, almost exclusively Jewish, closely connected with Liberman and known as "Berlin Section" or even "Jewish Section". This group acted as a liaison between Russian revolutionaries in their native country and in emigration. They smuggled illegal publications into Russia, forwarded letters and reports from there to the revolutionaries abroad, helped revolutionaries to get in and out of Russia, etc. When the article "Prejudices of our Social Revolutionaries against Jews" arrived in Berlin, Gregory Gurevich, a leading member of the "Berlin Section" and a future co-defendant of Liberman in the Berlin trial of April $1879,{ }^{4}$ decided

\footnotetext{
1 This pamphlet was: V. Varzar, Khitraia Mekhanika (The Cunning Mechanism), published by Vpered.

2 "Budet buria", in: Vpered 1876, nr. 36.

3 Letter from Moskvich to Vpered, May 10, 1876 . His correspondence was published in Vpered, the bi-monthly edition, $1876, \mathrm{nr} .35$.

4 For the history of this trial, see: G[urevich], Pervyi protsess nigilistor $\vee$ Berline, in: Byloe, I907, nr. 9, pp. 77-82.
} 
to keep it for a while to get acquainted with its contents. Later he mailed the "Prejudices" to London and let Vpered know that he and the Berlin Section did not approve of the manuscript. ${ }^{1}$ The author of the "Prejudices" remains unknown. ${ }^{2}$

It would hardly be an exaggeration to state that in the 'seventies and, as a matter of fact, in the 'eighties, and the 'nineties, until the emergence of the "Soiuz Sotsial-Demokratov" and of the Bund, Vpered and the Lavrists had been the only Russian revolutionary group that actively supported aspirations of the Jewish socialists and stimulated the building up of a Jewish socialist movement. An attempt in this direction was made in the 80 s by Michael Dragomanov, an Ukrainian leader. But nothing came of his efforts and very little is known about the circumstances in which they were undertaken.

\section{III}

\section{SOCIALISTS-JEWS CONNECTED WITH VPERED}

Closely associated with $V$ pered though they were, the Jewish socialists, such as Liberman and his supporters in the Berlin Section were not Lavrists. The same holds true of the Vilno circle (kruzbok) liquidated by the police in June 1875 . The Jewish socialists in London, Berlin and Vilno, although influenced in many respects by Lavrov and his mouthpiece Vpered, did not consider themselves and were not regarded by others as Vperedovtsy.

In the course of its multifarious activities Vpered attracted, came to know and dealt with a number of Jews about whom it is not always easy to say whether or not they were Jewish socialists in the sense Liberman was one, but who in no way were Lavrists. It should be borne in mind that there were hardly any revolutionaries from the Russian empire - Russians, Poles, Ukrainians, Jews - who, while abroad, did not approach Vpered, this address of the so called Russian Social-Revolutionary Party, on one question or another. About the same was true regarding revolutionaries within Russia. They had to contact Vpered at one time or another.

Thus, the names of men like Arkadi Finkelstein, Lazar Goldenberg, Mark Natanson, Aron Zundelevich and of young women like Anna Epstein, Betsi Kaminskaia are to be found in the archives gathered by Smirnov. I refer only to the Jewish people most prominent in the 'seventies who either wrote letters or approached

1 G. Gurevich to the redaction of Vpered, April 2, 1876.

2 A yiddish translation of "Prejudices..." was published in "Unzer Tsait", Warsaw 1929. 
$V$ pered or rendered services to the publication of Lavrov. (The members of the "Berlin Section", for instance Aronson, Gurevich, Matvei Romm, are not mentioned here since they were Jewish socialists. Saper, though a member of the Agudah will be dealt with later.) Some of them rendered services to Vpered or even belonged to its technical staff. Goldenberg worked in the Vpered printing shop; Finkelstein and, particularly, Zundelevich smuggled publications of Vpered into Russia and served as liaison between Vpered and the Lavrists in Russia; Natanson was the man who, in 1876 , succeeded in arranging for a short while a merger of $V$ pered with other Russian revolutionary factions; Anna Epstein was instrumental in the distribution of Vpered within Russia. Nevertheless, none of them identified themselves with the Vpered group nor was viewed by the latter as Lavrists.

Anna Epstein who became the wife of Dmitrii Klements, Betsi Kaminskaia co-defendant of Lubatovich, Bardina and others in the so called trial of the so (March 1877 ) - sympathized with the Bakunists. Natanson, the father of the "Zemlia i Volia", did not share the political views of Vpered. Goldenberg joined the staff of $V$ pered as a result of the unifying action of Natanson and represented in London other factions than Lavrists. There remain Finkelstein and Zundelevich whose political allegiance in the 'seventies one is entitled to question.

As far as Finkelstein, the main personage in the Vilno kruzbok in 1872 , is concerned, who between 1873 and the beginning of 1876 lived in Königsberg and had been forwarding Vpered to Russia (à propos, on October I 8,1875 he wrote to Smirnov that his - Finkelstein's report on Vilno was published in the Cbemnitzer Freie Presse) there is a letter of Ginsburg of January 5, I 874, in which the leader of the Lavrists in Russia refers to Finkelstein as a friend of the Bakunists. In another letter written on the following day, Ginsburg, who at that time was busy establishing channels for smuggling Vpered to Russia, pointed out that he did not want to initiate Finkelstein into his dealings with smugglers because Finkelstein maintained close contacts with Michael Sazhin (Armand Ross), head of the Bakunist caucus. Such was the situation in 1874 . It may be that later Finkelstein changed his mind. In the Vpered there are two articles by Finkelstein: "From Köningsberg" and "German Administration, Courts and Press subservient to Russia". "After Finkelstein had to escape from Germany and went to Paris where he took over the apartment of Herman Lopatin, his traces disappeared from the annals of $V$ pered.

1 The bi-monthly edition, $x 875$, nr. 4 and $x 876$, nr. 30 respectively. 
Quite different was the case of Aron Zundelevich, this admirable figure of a Russian-Jewish revolutionary in the 'seventies. His biography is sufficiently known. Here it will be touched upon solely as far as his relationship with Vpered is concerned. Beginning about mid-1 875, first together with Finkelstein in Königsberg and from 1876 onward, alone in Memel and in Berlin, Moishe or Zund - as he was called tenderly by his friends - had been postmaster general as well as minister of communications of $V$ pered. He was also associated with Liberman and advised him in questions pertaining to the publication of Haemes. Zundelevich, who read $V$ pered in Vilno prior to his escape from there in June 1875 , appreciated the high intellectual standard of the publication and - as a well organized man - highly rated the regularity of its appearance. As long as there were no other organs to compare with and no other revolutionary groups able not only to proclaim but also successfully to implement a different political outlook than that of Vpered, Zundelevich remained faithful to the Lavrists without being one of them. As a matter of fact, like his predecessor Finkelstein, he never limited his services to Vpered only, although in a letter to Smirnov of November 23, I875, he referred to Vpered as "our newspaper". This changed later on. Natanson, who late in 1875 negotiated a merger of all revolutionary factions in a united organization, visited Zundelevich and drafted him for plans which led towards the foundation of the Zemlia i Volia. In the meantime from his Königsberg-Memel-Berlin vantage position Zundelevich followed the developments in Germany, i.e., the progress of the Social-Democratic Party and grasped faster than many other Narodniki, in and outside Russia, the enormous importance of political freedom for his native country. He also realized that political action there required methods not acceptable to the $V$ pered people and he moved away from them. After having received and read volume $V$ of the non-periodical edition of Vpered (1877) he wrote to KuliabkoKoretskii on December 30, 1877: "I still regard you and your friends as my comrades in a general but not in a narrow sense of this term... You refuse to understand that Russia is a country where nothing else can be done but putsches."

\section{IV}

\section{JEWISH LAVRISTS}

So far we dwelled on the periphery of Vpered and it was there that we were able to list Jewish socialists as well as socialists-Jews, some of whom were more and some less and some not at all influenced by 
Lavrov's theories, but none of whom could be identified with the Lavrists. If we now take up the internal circle of $V$ pered and its followers, we meet Jewish Lavrists in the proper sense of this word. Two, and the most important of them, have been known to historians of the 'seventies. Their actual role, however, has never been spelled out. The late E. Tscherikower refers to these two Lavrists, Lev Savel'evich Ginsburg and Rozalia Khristoforovna Idelson, as follows: "In the [existing] literature, unfortunately, there are very few data regarding these two representatives of the 'Lavrists'. L. Deutsch does not mention them at all". 1

To Ginsburg and Rozalia Idelson Kuliabko-Koretskii refers in his memoirs and on Ginsburg there are interesting comments in the memoirs by Ieronim Iasinskii. ${ }^{2}$ On the whole, however, 'Tscherikower was right, complaining about the dearth of data in historical writing regarding Ginsburg and Rozalia Idelson which may be partly explained by the fact that both of them, though for different reasons, severed their ties with the revolutionary movements in the course of the 'eighties.

In the following I am going to make use of data preserved in the Smirnov archives referring to Ginsburg and Rozalia Idelson as well as to other Jews in the set-up of Vpered. It should be borne in mind that all the Jewish Lavrists were socialists-Jews and not Jewish socialists and that their activities belong, in the first place, to the history of the Russian revolutionary opposition against the Romanov's rule in the 'seventies.

\section{Lev Ginsburg}

Lev Savel'evich Ginsburg who died in Petrograd in 1916 as a medical doctor, specialist in dentistry, hailed from the Russian Ukraine and attended gymnasium in the town of Chernigov. He graduated from this school in 1867 or 1868 and enrolled in the medical school of the University of Kiev in 1868 . His family lived in Chernigov where they probably had a small business. Thus, after his father's death, which occurred in 1870 , the young Leo, since 1869 student of the medical school in St. Petersburg, "Voenno-Meditsinskaia Akademia", had to support himself, which he did by giving lessons and working on translations.

${ }^{1}$ Historishe Shriftn, Vol. III, Vilno 1939, p. I 27 note 242. Tscherikower's information about Deutsch is not correct. Deutsch does mention the name of Ginsburg and even indicates that he was a second-rate leader; see Deutsch, op. cit. p. 34.

2 Roman moei zhizni, Moscow-Leningrad x 926. 
Ginsburg possessed practical abilities which made of him an irreplaceable advisor to his fellow students and friends and later on made him a chief fund raiser of $V$ pered. Ieronim Iasinskii tells how Ginsburg procured work for him in $1872 ;^{1}$ from the correspondence between Ginsburg and Rozalia Idelson we learn that Ginsburg if not fully footed the bills of Rozalia in Zürich, at least largely contributed toward her budget there in the years $1871-1874$; the same source reveals that Ginsburg arranged for some job for Rozalia Idelson's husband, Smirnov, who at that time helped Lavrov with the first volume of $V$ pered; further it was certainly Ginsburg who in 1874 induced medical students to transmit to Vpered the total amount of their collective funds - I,000 roubles. It seems that he inherited from his businessman father a certain ingenuity in dealing with daily life problems which was happily married in him with innate decency, reliability and common sense.

A typical representative of the "raznochinnaia" or people's intelligentsia, he read Chernyshevskii and worshipped Chto delat"? ("What is to be done?") as well as studied "Historical Letters" and became an admirer of their author, Mirtov-Lavrov. His attempts to promote the medical studies of Rozalia Idelson in Switzerland were, of course, determined by the fact that he was in love with Rozalia but also by his sense of duty to help, as he formulated it in one of his letters "an intelligent, decent young woman wishing to support herself by her own work."

He was a serious and gifted man who liked to study and who seemed to have been a little too bookish as compared with the Narodniki of action. It is, for instance, impossible to imagine him in the role of a terrorist. But his perfect willingness to sacrifice himself for a cause, his readiness for self-denial and his lack of egotism - cannot be doubted. To obtain funds for $V$ pered at a moment when all normal sources were exhausted, Ginsburg, together with some other Lavrists accepted a medical job in a region infested with bubonic plague and let $V$ pered have the money they earned on this dangerous assignment. Although the recognized leader of the Lavrists in Russia, he hardly ever tried to be more than primus inter pares.

Already as a schoolboy he liked, according to Ieronim Iasinskii, exactness and had confidence in facts only. Hence his predilection for science: with permission of the principal he organized a chemical laboratory in his Chernigov gynmasium ${ }^{2}$. But abstract problems too were not alien to the precocious boy. As was typical for a Jewish intellectual of his time, of the foreign languages he knew German and

1 Iasinskii, op. cit. p. 96.

2 Idem, p. 66. 
as early back as in his gymnasium years he studied Kant in the original. "I as well as all his fellow students were convinced that he would make a brilliant scholarly career" - noted Iasinski. ${ }^{1}$ Ginsburg, however, had chosen another road, I don't know whether it was to his liking but certainly in accordance with his Weltanschauung and in the spirit of the idealistic traditions of the Russian intelligentsia.

I am not able to indicate when exactly and under what influences Ginsburg became a socialist and a revolutionary. Iasinski reports that already in Chernigov Ginsburg took part in kruzbki devoted to self-education and discussions of politically delicate topics. ${ }^{2}$ Later on, when in the medical school of the Kiev university he witnessed and probably got involved in the riots which, by the end of the 'sixties occurred in the academic institutions in the Russian capital and in provincial universities. It is interesting to note the names of youths he met in Chernigov and afterwards in Kiev, nearly all of whom were related to the socialist opposition of the 'seventies: Armashevskii, Grechanik, Rashevskii, Ivan Chernyshev, Varzar, Zubko-Mokrievich. Of them only the first later changed his outlook drastically and switched to an extreme right-wing group. Of the others, from the point of view of Vpered, Vasili Varzar is particularly important, a well known statistician, an active supporter of the Lavrists and the author of the booklet Kbitraia Mekbanika, the most popular propagandist tract used all over Russia in revolutionary circles of the 'seventies.

Even more important in the framework of this study is another name, that of Sergei Podolinskii, whose antisemitic disposition has been recorded above. Podolinskii was one of the links in the chain which connected certain socialist groups with the founding of $V$ pered. The origin of Vpered, which still remains a mystery, cannot be discussed here. As far as Ginsburg is concerned, it is significant that it was Southern Russia where the plan had been conceived to go to the author of the "Historical Letters", i.e., Lavrov and suggest to him the foundation of a publication which became Vpered. It was not Podolinskii who was entrusted with such a mission. But Podolinskii not only was au courant of this plan, he was present in Paris early in 1872 when the delegation from Russia visited Lavrov. He went back to Russia and there spent the time between April and July i 872 to collect funds for the publication suggested to Lavrov and he followed the latter to Zürich, where Lavrov intended to draft a team for $V p e r e d$.

It was not a pure coincidence that Ginsburg appeared in Zürich almost simultaneously with Lavrov and Podolinskii (he was certainly

1 Idem, p. 75.

2 Idem, p. 66. 
there in November 1872). Podolinskii knew Rozalia Idelson well, whom Ginsburg had met either in St. Petersburg or in the Ukraine some time in I 869 or may be earlier since in August 1869 he spent some time with her in Nezhin and was then her close friend to say the least. In the summer of 1870 Rozalia Idelson was in Kiev, she there met friends of Ginsburg's and in the same year she had letters from Podolinskii with allusions to a revolutionary publication to be established for distribution in Russia. Ginsburg knew and informed Rozalia Idelson about the forthcoming trip of Podolinskii to Paris early in 1872 . It may, therefore, be assumed with a great degree of likelihood that Ginsburg and Rozalia Idelson were connected or, to be more cautious, had dealings with those who went to Lavrov and induced him to undertake the publication of Vpered.

The delegation which approached Lavrov in Paris in March 1872 , did not even enter the annals of $V$ pered. Its members vanished from the scene as suddenly as their visit was unexpected by Lavrov. It so happened that their places were taken by their friends or acquaintances, Ginsburg and Rozalia Idelson for good, and Podolinskii for a while, who together with people whom Lavrov selected in Zürich - the most outstanding among them Valerian Smirnov - shouldered the heavy burden of establishing and maintaining Vpered. While Smirnov and Rozalia Idelson acted together with Lavrov in Switzerland and later in Great Britain, Ginsburg, who returned to Russia in December 1872 or in January 1873 , became the central figure of the Lavrists in Russia for the years to follow. From time to time he was making trips to the headquarters of Vpered. This was the case in 1873,1874 , I 875 and I 876 . He also contributed articles to Vpered ${ }^{1}$ which, particularly that entitled "Letter to Graf K.I. Palen", reveal Ginsburg as an attentive and sober observer of Russian life, whose eyes discerned and whose pen described with astonishing clarity the headway made by capitalism in Russia after the reforms implemented by Alexander II. The letters by Ginsburg show him as an irreconcilable adversary of the Bakunist faction. Neither his articles nor his letters deal with any Jewish topics. During the period we are dealing with he lived beyond any Jewish problems as if they did not exist for him or as if he was completely detached from them. Therefore, it is interesting to register his reaction to an anti-Jewish remark by one of his contacts in Galicia where he looked for means of smuggling Vpered into Russia. This contact referred to Jewish smugglers rather scornfully: "A Jew

1 These are in Vpered the non-periodical edition: Chaos of the Bourgeois Civilization (Vol. I, Part 2, pp. 97-119), Who is destroying the mainstay of the Society (Vol. II), Evgenii Stepanovich Semianovskii (Vol. V); in Vpered, the bi-monthly edition: Letter to Graf K. L. Palen (1875, nr. 16). 
always remains a Jew". Seemingly shocked by this expression, Ginsburg hastened to correct the man by answering (they conversed in German): "Ein Gelderwerber bleibt immer ein Gelderwerber."1

\section{Rozalia Idelson}

The third in the triumvirate, without whom Lavrov would hardly have been able to manage Vpered, was a young woman, Rozalia Khristoforovna Idelson, the first two being Smirnov and Ginsburg.

Neither a writer nor a political leader; barely provided with any outstanding intellectual gifts, although energetic and positively not foolish; probably charming though hardly a beauty - she attracted men and possessed a rare ability to inspire them. She was also liked, which happens less often with that type of girl, by members of her own sex, and she was always involved in some public affair. Her political activity came to an end when, rather late, she became a mother. Then, it was in the 'eighties, she definitely abandoned the revolutionary sphere of action from which she had already been removed since about I $878 / 79$ and devoted herself to her son whom she adored.

There are good reasons to believe that her socialist convictions were a little superficial and that her volatile mind gravitated with equal intensity towards ideas as towards fineries. But she could be a devoted friend and her dedication to the revolutionary cause was a genuine one. She did not lack courage and perseverance, was one of the striking features of her character. Rozalia Idelson, evidently, was not of the caliber of Vera Figner or Bardina or Anna Rosenstein (Makarevich-Turati) - her contemporaries who adorned the Russian horizon in Zurich. Her dealings and doings, I am aware of that, belong rather to the petite histoire of Vpered. Nevertheless, without her the history of Vpered and of the Lavrists would be incomplete.

Born as Rassia in Vilno, on October ro, 1848 (her birth certificate was kept in Smirnov's archives) from Sara-Sheina and Khaim Iakershberge $^{2}$ she ended her days during World War I in Petrograd as the wife of a Russian general Evgenii Liakhnitskii, an army physician. An account of her life sounds like the plot of a novel of adventure and, as a

1 From a letter of Ginsburg to Smirnov, October 5, probably I 873.

a Sazhin calls her mother Mrs Rosenblat, see M.P. Sazhin, Russkye $v$ Tsiurikhe, in: Katorga i Ssylka, 1932, nr. Io. This may have been the name of her second husband or her maiden name, although I could not find any indication of her second marriage nor of a divorce from Khaim Iakershberg. 
matter of fact, to write about her would represent a gratifying task for a fiction writer.

She was about 17 when Michael Sazhin, later on right hand and confidant of Mikhail Bakunin, arranged for her in the synagogue of Tsarskoe Selo a marriage with a student of the Technological Institute in St. Petersburg, a certain Idelson. Hence her last name Idelson. This wedding had been planned as a mariage blanc, with the purpose to withdraw young Rozalia from the guardianship of her mother, who did not want her daugher to be influenced by Russian students to whom she used to let rooms and who became interested in Rozalia and in her sister Anna. It is an open question whether Rozalia's matrimony remained, as it was conceived, a fictitious one. Sazhin, to whom we are indebted for this story, tells that the couple Idelson consummated their union. Anyhow, if it was not a mariage blanc it was, in any case, a mariage de raison. I don't know what happened to Mr. Idelson, but from the life of Rozalia he vanished completely shortly after their marriage.

Rozalia yearned for an education. She longed for a profession which would make her independent. She dreamed to be trained as a physician. In Russia, at that time, it was quite difficult if not impossible to attain such a goal for a girl in general, for a girl without means in particular, let alone for a Jewish girl. As far as I could establish, Rozalia had never attended a gymnasium. All she can be credited with was a teacher's diploma (s.c. house teacher) obtained with the help of the same Sazhin who, en passant, did appreciate not only her urge for education.

To acquire a doctor's diploma, Rozalia Idelson decided to go to Switzerland. In the meantime she met Ginsburg, which apparently affected her correspondence with Sazhin, who in I 868 and I 869 lived under surveillance of the police in Vologda and complained that she did not write often enough to him. Ginsburg got some funds and promised to supply money; some other financial resources became available to Rozalia and in August $187 \mathrm{I}$ she was already in Zürich where she met Valerian Smirnov, a political emigré from Moscow, who became her husband. Ginsburg did not discontinue sending money to Zürich, although as time went by this source of Rozalia's income became more and more scarce. Smirnov also took care of his wife within the limits of his very modest means. Still another man, Evgenii Anatol'evich Liakhnitskii, whom Rozalia knew in St. Petersburg and who took a job in Turkestan, helped from time to time. It was a hard life. But Rozalia's strong will overcame trivial difficulties. She could not continue her studies in Zürich, tried without success to register in the Paris medical school (at the end of I 873) and 
then settled in Bern where only in $\mathrm{x} 88 \mathrm{I}$ she finally attained her goal. At that time Smirnov and his wife were not able to make ends meet and Rozalia decided to take medical examinations in Russia. It is possible that already then she was prepared to leave Smirnov. At any rate there are letters in the Smirnov archives, written by Liakhnitskii in November and December 1881 and in January 1882 , in which he implored Rozalia to return to St. Petersburg. And she did so.

I do not know when Rozalia's mother moved to St. Petersburg and I cannot indicate anything about her father and brother Moishe. ${ }^{1}$ However, various letters preserved in the Smirnov archives show that Rozalia was well acquainted with and popular among the revolutionary youth of the Russian capital. She was connected with the Chaikovtsy, especially with the group of young women who formed a part of the Chaikovtsy organization. She attended the school caucus (shkol'nyi kruzbok) which gathered at the home of the sisters Kornilov, knew well A. Iak. Obodovskaia, N. K. Skvortsova and was on friendly terms with Mrs. M. K. Tsebrikova. Having had relatives in the Ukraine, she travelled to Kiev, Chernigov and Nezhin; took part in the discussions leading, finally, to the sending of a delegation to Lavrov. In Zürich it took her not long to be appointed librarian of the Russian students library founded by Sazhin (1872). It was Sazhin who suggested to her (prior to the rupture between the Bakunists and the Lavrists) to join a revolutionary organization planned by him. The wife of Smirnov, a close friend of Ginsburg and an old acquaintance of Podolinskii, she associated herself with the Lavrists and early in i 873 undertook a risky trip to Russia on behalf of Vpered. Lavrov had been attached to her and she was one of those whom he entrusted with the transcription of his manuscripts which, due to his illegible handwriting, few people were able to decipher. When $V$ pered moved to London, Rozalia Idelson remained in Switzerland to go on with her medical studies and it is touching to observe how thoughtfully all members of the Vpered community in London, who truly had other and more burning worries, encouraged Rozalia's efforts to graduate from medical school. Rozalia Idelson knew literally everything about the Vpered community in London and the Lavrist propaganda in Russia. Smirnov used to write to her almost daily detailed letters which contain the annals of Vpered. Lavrov too, less often but quite regularly, corresponded with her. Separated geographically from London and St. Petersburg she remained the first lady of the Lavrists as long as this group was able to act.

1 Sazhin refers to the latter, see Sazhin, op. cit. 


\section{Dii Minores}

To exhaust the list of the Jewish Lavrists I have to introduce, in addition to Ginsburg and Rozalia Idelson, several people some of whom are well known, most of whom, however, are either utterly forgotten or not known enough as Lavrists, and all of whom had their share in the history of Vpered, though not all of them were Lavrists pur sang. These people are in alphabetical order: Chudnovskii, Solomon; Iokhelson, Vladimir; Mandelbaum, A.; Margolin, Moisei; Pavlovskii, Aron; Saper, Girsh; Shnee, Samuil; and Weisman, Boris. Iokhelson and Chudnovskii left detailed memoirs ${ }^{1}$ and for the purpose of our study it suffices to register their names only. On Mandelbaum I am able solely to record his story about students in the Swiss universities placed in the $V$ pered bi-monthly. ${ }^{2}$ On the others I have to dwell somewhat longer.

Grigori (or Girsh) Davidovich Saper, who was born and died in St. Petersburg in 1849 and 1902 respectively, and who left Russia for abroad in $1872,{ }^{3}$ wrote in London on January 1 , 1876 to the editorial board of Vpered: "This is the fourth year that I live in a foreign country. You opened my eyes by supplying me with your publications." He became a frequent guest in the London premises of $V$ pered and felt a genuine friendship for Lavrov and Smirnov. He met, of course, the Jewish type-setters of Vpered, Goldenberg and Liberman, and was, like them, a founder-member of the Agudah Hasotsialistim Haivrim, which he wanted to convert into a Bildungsverein.

It seems that non-Jewish socialist activities drew his attention even more strongly than those of the Agudah. He used to attend meetings of the German socialists in London and he was one of the speakers in the international rally organized in London by political refugees from various countries on the occasion of the thirteenth anniversary of the Polish uprising of $1863 .{ }^{4}$ The Smirnov archives preserved: his invitation addressed to the $V$ pered community in which he urged his "dear compatriots" to take part in a gathering against the treatment inflicted upon the former French communards in New Caledonia and his lenghty letter discussing the exploitation of Jewish workers, newcomers in London.

1 V1. Iokhelson, Dalekoe proshloe, Iz vospominanii starogo narodovol'tsa, in: Byloe I918, nr. I3 ; S. L. Chudnovskii, Iz dal'nikh let (Otryvki iz vospominanii), in: Byloe 1907, nr. 9; S. L. Chudnovskii, Iz dal'nikh let, Moscow 1934.

2 "From Bern", 1876, nr. 35 .

- Deiateli revoliutsionnogo dvizheniia v Rossii, bio-bibliografischeskii slovar', Vol. II, issue 4, Moscow 1942, sub voce.

- Meeting held on January 22, 1876 . See report in Vpered, the bi-monthly edition, 1876, nrs. 27 and 28: The Anniversary of the Polish Insurrection of 1863 in London. 
Margolin and Pavlovskii were both involved in the so called great trial of the 193 (October I 877-January I 878) and both were released since the police lacked evidence against them. However their relationship to Vpered remained unknown to the authorities and to the editors of the Bio-bibliograficheski slovar' too.

Moisei Isaakovich Margolin (known in Vpered circles under the pseudonyms Moiseev, Vasili Ivanovich or Moisei Ivanovich) was born in $185 \mathrm{I}$ in Kherson, deported to Siberia in 1879 and returned to European Russia seven years later; he studied first in the University of Odessa and then in the Mediko-Khirurgicheskaia Akademiia in St. Petersburg. This information is given in the Bio-bibliografischeskii slovar'. ${ }^{1}$ According to the same source Margolin, arrested in connection with the "going to the people" movement (I 874), was released on February 19, 1876 . But Smirnov refers to him in his letter to Rozalia Idelson of December 6, I875 (I cannot reconcile this discrepancy) and tells that Margolin is in London where he is busy studying Marx. He remained in the British capital for about six months and worked as a type-setter of $V$ pered. He returned to Russia early in the summer of 1876 as a full-fledged Lavrist, contacted in Moscow the Vpered representative there, Dmitrii Ivanovich Rikhter and proceeded via Odessa to his native Kherson. From Odessa he sent a report to London on the break between the Lavrists and the Natanson group which occurred in St. Petersburg and on the Lavrists activities in Southern Russia.

Pavlovskii, Aron Iakovlevich - brother of Isaak Pavlovskii, a turncoat who started as a revolutionary and ended as a contributor to the reactionary newspaper Novoe Vremia (The New Age) - approached Vpered in April i 877 from New York where he had a job with some store supplying commodities to Russian boats. He used this situation to conduct revolutionary propaganda among Russian sailors. In the U.S.A. he assumed the name of Hertz. In the autumn of the same year he left New York for Ohio to work on a farm from where he maintained contact with Nicolas Chaikovskii. Since 1877 was the year of the beginning of the end of the Lavrists, it is doubtful whether Pavlovskii's approach to Vpered had any tangible results. His name has not been dropped from this study for the sake of accuracy.

There remain two brothers Samuil Abramovich Shnee and Boris Abramovich Weisman who hailed from Southern Russia and were contact men of Vpered in Constantinople, Turkey. How it happened that they had different last names, I do not know. The senior of them,

1 Deiateli revoliutsionnogo dvizheniia $\mathrm{v}$ Rossii, bio-bibliograficheskii slovar', Vol. II, issue 3, Moscow 1931 , sub voce. 
Samuil, had been converted to the socialist faith by Russian revolutionnaries. Among his acquaintances were the well known narodnik Ivan Martynovich Kovalskii and a member of the technical staff of Vpered, the type-setter Iakov Vasil'evich Voshchakin. The latter, an interesting type of a Russian educated worker, a seeker of truth, versed in the Holy Scriptures and devotee of $V$ pered, from time to time accepted jobs on Russian boats as a stoker to proselytize among their crews and, particularly, to draft agents able and willing to smuggle Vpered into Russia. On one of his trips he probably discovered in Constantinople a young Jewish retoucher photographer who had escaped from Russia to avoid the draft. Samuil Shnee proved to be an excellent liaison between Vpered and the Russian sailors drafted by Voshchakin. Moreover, Shnee, on his own, conducted revolutionary propaganda among Russian sailors and even among Greek Orthodox pilgrims passing Constantinople on their way to Jerusalem. He was also interested in the situation of the working classes in the Turkish capital and supplied $V$ pered with information gathered by him. On October 27, I875, he wrote to London: "Thanks to my knowledge of Yiddish [he writes - Jewish language but means, I am sure, Yiddish] I succeeded in collecting data on tailors and shoemakers..."1 The sailors informed Shnee about their life. Thus he was able to compile for Vpered a story "Revolt on the Boat 'Azof"'.2 He was apparently informed about the plans of Liberman. Thus, in his letter quoted above, he refers to "our future Jewish printing shop". The beginning of the contact between Shnee and Vpered dates from August 1875 . About one year later he decided to return home. But it was not his intention to foresake the cause. He found a deputy, his younger brother Boris who introduced himself to Vpered in November I 876 in the following terms: "It is with joy that I take upon me the duties of my brother Samuil and I want to help you in forwarding your publications to Odessa and to other places." He kept his promise, remaining at his post until July i 878 . It is a moot question how deep was the Lavrist allegiance of both brothers, Samuil and Boris. In one of his letters dated November 3, I 876, Samuil told Vpered that he was willing to forward, horribile dictu, Nabat ("Tocsin") of Tkachev to Russia. One can imagine the consternation caused by this letter in London.

1 These data were used in "From Constantinople", published in Vpered, the bi-monthly edition, 1876, nr. 29.

2 Vpered, the bi-monthly edition, 1876 , nr. 30 . 
SOME CONCLUSIONS

The scope of this study is too limited to allow any far reaching conclusions. However, the material at our disposal justifies some closing remarks regarding socialits-Jews whom we met in the framework of the Vpered activities.

The attitude of these socialists towards Jewry was about the same as that of Jews who in the 'seventies joined other revolutionary groups. All of them rebelled against the established political and social system prevailing in Russia as well as against the traditional Jewish heritage and it seems that their repudiation of the latter was even stronger than that of the former.

It was in the spirit of the time that they, like non-Jewish socialists in and outside Russia, underestimated or even refused to attach any importance to national problems. The cosmopolitan outlook which characterized the 'seventies, but also the following decades until the emergence of the Bund, was not actually revised in Russia before World War I. "Hommes de bonne volonté" (using the term of Jules Romain), socialists-Jews of the 'seventies professed a complete indifference towards all things Jewish. "It can be asked", wrote Vladimir Iokhelson, "why we wanted to be active within the Russian and not the Jewish people. This finds its explanation in our estrangement from the culture of the Russian Jews and in our negative assessment of their religious and bourgeois leaders... Regarding the Jewish lower classes we thought that the liberation of the whole of Russia would bring along the liberation of all nations living there... One has to admit that Russian literature has instilled in us a view that Jewry was not a nation but a parasite class."1 Of course, Jewish socialists, such as Liberman, did not fully share this view. But they constituted a minority.

As has been pointed out earlier (see p. 368 ) some socialists-Jews referred to Jews as kikes ( $($ bidy). Aron Pavlovskii wrote to Vpered from New York that he was employed by a zhid who supplied commodities to Russian boats in the New York harbor. Aron Zundelevich told Vpered that he was negotiating with "zhidy" to arrange for smuggling revolutionary publications into Russia. To be as close as possible to the "poor, oppressed and miserable" Russian peasant, a man of great heart and of fine feelings, Osip Aptekman, became converted to Greek Orthodoxy. It is, therefore, interesting to note

1 Iokhelson, op. cit., pp. 56-57. 
that in certain situations socialists-Jews identified themselves with Jewish people. This was the case when they were confronted with overt anti-semitism on the part of some of their non-Jewish comrades, particularly after the pogroms in the 'eighties. In I 887 Osip Aptekman sent a moving letter to his old friend, Pavel Axelrod in which he wrote that his heart was bleeding when he heard about anti-Jewish outbursts in Southern Russia. ${ }^{1}$

On the whole, however, socialists-Jews of the 'seventies became gradually more and more alienated from the Jewish collectivity and ultimately completely adopted Russian culture and many of them were absorbed by the dominating Russian nation. Atheistic as they were, they lacked religious ties with the Jewish traditions. Internationalism, as they professed it, deprived them of the will to develop a Jewish secular culture, regardless whether this was viable or not.

There have been several avenues which led the young Jewish intelligentsia away from their own milieu. Socialism of the 'seventies was one of them. This is meant not as a judgment but as a factual statement.

My knowledge of the Russian-Jewish, Yiddish or Hebrew belles lettres is very scanty and I don't know whether there are novels depicting Jewish youth of the 'seventies as for instance Levanda did for the 'fifties and 'sixties (Goriacbee vremia) and Sholem Ash ("Three Cities") for the period of World War I. Gorky once suggested to republish in Russia a series which he called a history of a young man, having in mind books like Le rouge et le noir, Education sentimentale or Confession d'un enfant du siècle. A similar series dealing with Jewish youth from the 'seventies up to the emergence of the Bund would present a picture of assimilation resulting from a conversion to the socialist faith.

1 Letter of 16 August, Axelrod archives, IISG, Amsterdam. 